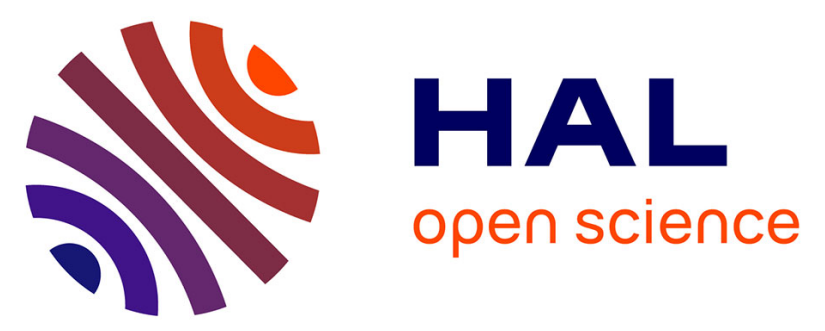

\title{
Potentially toxic element phytoavailability assessment in Technosols from former smelting and mining areas
}

\author{
Bashar Qasim, Mikael Motelica-Heino, Emmanuel Joussein, Maryline
}

Soubrand-Colin, Arnaud Gauthier

\section{- To cite this version:}

Bashar Qasim, Mikael Motelica-Heino, Emmanuel Joussein, Maryline Soubrand-Colin, Arnaud Gauthier. Potentially toxic element phytoavailability assessment in Technosols from former smelting and mining areas. Environmental Science and Pollution Research, 2015, 22 (8), pp.5961-5974. 10.1007/s11356-014-3768-9 . insu-01145556

\section{HAL Id: insu-01145556 \\ https://hal-insu.archives-ouvertes.fr/insu-01145556}

Submitted on 5 Jun 2015

HAL is a multi-disciplinary open access archive for the deposit and dissemination of scientific research documents, whether they are published or not. The documents may come from teaching and research institutions in France or abroad, or from public or private research centers.
L'archive ouverte pluridisciplinaire HAL, est destinée au dépôt et à la diffusion de documents scientifiques de niveau recherche, publiés ou non, émanant des établissements d'enseignement et de recherche français ou étrangers, des laboratoires publics ou privés. 


\title{
Potentially toxic element phytoavailibility assessment in Technosols from former smelting and mining areas
}

\author{
Bashar Qasim ${ }^{1,2, *}$, Mikael Motelica-Heino ${ }^{1}$, Emmanuel Joussein $^{3}$, Marilyne Soubrand $^{3}$, \\ Arnaud Gauthier ${ }^{4}$ \\ ${ }^{1}$ CNRS/ISTO Institut des Sciences de la Terre d'Orléans, UMR-CNRS 7327 Campus \\ Géosciences, 1A rue de la Férollerie, 41071 Orléans, France. \\ ${ }^{2}$ Applied Sciences Department, University of Technology, Baghdad, Iraq. \\ ${ }^{3}$ Université de Limoges, GRESE, EA 4330, 123 avenue Albert Thomas, 87060 Limoges, \\ France. \\ ${ }^{4}$ Laboratoire de Génie-Civil et géo Environnement, LGCgE-EA4515, Université Lille 1, \\ 59655 Villeneuve d'Ascq, France.
}

\begin{abstract}
This study reports the chemical bioavailability of several potentially toxic elements $(\mathrm{Zn}, \mathrm{Pb}$, $\mathrm{Cd}$, $\mathrm{As}$ and $\mathrm{Sb}$ ) in contaminated technosols from two former smelting and mining areas. Though these elements have long been recognized as a potentially harmful elements, understanding of their toxicity and environmental behavior in technosols developed on former mining and smelting sites are more limited, particularly for As and Sb. Surface soils were sampled from metallophyte grassland contaminated with $\mathrm{Zn}, \mathrm{Pb}$ and $\mathrm{Cd}$ located at Mortagne $\mathrm{du}-$ Nord (MDN) (North France) and from a former mining settling basin contaminated with $\mathrm{As}, \mathrm{Pb}$ and $\mathrm{Sb}$ located at la Petite Faye (LPF) (Limoges, France). Various selective single extraction procedures $\left(\mathrm{CaCl}_{2}, \mathrm{NaNO}_{3}, \mathrm{NH}_{4} \mathrm{NO}_{3}\right.$, DTPA and EDTA) were used together with germination tests with dwarf beans whose shoots were analyzed for their potentially toxic element concentrations after 21 days of growth. The extraction capacity of the potentially toxic elements followed the order: EDTA $>$ DTPA $>\mathrm{NH}_{4} \mathrm{NO}_{3}>\mathrm{CaCl}_{2}>\mathrm{NaNO}_{3}$ for both studied areas. Pearson's correlation coefficient analysis between the concentrations of potentially toxic elements accumulated in bean primary leaves or their mineral mass with their extractable concentrations showed a positive significant correlation with dilute $\mathrm{CaCl}_{2}$ and nitrate solutions extraction procedures. In contrast, for all studied elements, except $\mathrm{Pb}$, the complexing and chelating extractants (EDTA and DTPA) exhibited poor correlation with the dwarf bean leaves concentrations. Moreover results showed that the $0.01 \mathrm{M} \mathrm{CaCl}_{2}$ extraction
\end{abstract}


procedure was the most suitable and provided the most useful indications of metal phytoavailibility for studied elements.

Keywords: Potentially toxic element, Partial extraction, Bioavailability, Mining and smelting activities, Technosol

\author{
Abbreviations \\ EC Electrical conductivity \\ LPF La Petite Faye \\ MDN Mortagne-du-Nord \\ $\mathrm{Ng} \quad$ No growth \\ Ns No significant correlation \\ TOC Total organic carbon
}

\title{
1 Introduction
}

High metal and metalloid concentrations in soils have negative effects on terrestrial ecosystems and generate potential health risks (Brown and Calas, 2011). Mining and smelting activities are the major sources of metals contamination by release of a huge amount of potentially toxic elements (PTE) into the environment through wind and water runoff erosion (Razo et al. 2004; Navarro et al. 2008). The accurate estimation of PTE bioavailability in soils is becoming more important to improve the management of contaminated land. Thus, information about accumulation of different PTE in different vegetable species, as well as soil factors that control their bioavailability are very important issues (Xu et al. 2013).

Due to different and complex distribution patterns of PTE among various chemical species and solid phases, their total concentration in soils is not a good indicator of their availability (Abollino et al. 2002). It appears therefore that the knowledge of PTE availability and ecotoxicity is more suitable than their total concentration for predicting their transfer from the soil to plants and may provide useful information to improve environment risk assessment (McLaughlin et al. 2000; Menzies et al. 2007; Plaza et al. 2010).

There is no ideal definition of the bioavailable fraction of PTE in soil. The International Standards Organization's (ISO) defined bioavailability as the degree to which chemicals 
present in the soil may be absorbed or metabolized by human or ecological receptors or are available for interaction with biological systems (ISO 11074 (2005)). The bioavailability of PTE in soils depends on the PTE species and their partitioning between the solid phase and the soil pore water. In the past few decades, many studies have been realized to evaluate PTE phytoavailability and related their uptake by plants with their extractable fractions by different chemical agents (Houba et al. 1990; Gupta and Aten, 1993; Pascual et al. 2004).

A wide range of single and sequential extraction schemes have been designed in order to assess the different binding forms of PTE in soils. The mobility and toxicity of PTE in soils were assessed depending on their total concentration in the soil, as well as their specific chemical form, physico-chemical properties, their binding state and soil properties like $\mathrm{pH}$ and organic matter content (Nyamangara 1998). Water-soluble, exchangeable, carbonate associated, Fe/Mn oxide-associated, organic-associated and residual forms are often the geochemical forms in which PTE are believed to accumulate in soils. Water-soluble and exchangeable fractions are considered to be bioavailable while the mineral fraction is mainly not available to either plants or microorganisms (Rodriguez et al. 2009; He et al. 2005). However, the lack of selectivity of the extraction reagents and artifacts such as coprecipitation, reprecipitation and readsorption of previously released PTE are the main limitations of such procedures (Cornu and Clozel 2000; David et al. 2002).

PTE extracted by single extractants are usually considered as indicators of the availability in soils (Black et al. 2011; Chojnacka et al. 2005; McBride et al. 2003). In fact, techniques to estimate the bioavailability of PTE have focused on selecting suitable extractants and developing extraction procedures with different experimental conditions (Black et al. 2011; Anjos et al. 2012). The advantages of a single extractant test compared with a bioassay to determine bioavailability include the simplicity and reproducibility, reduced costs and reduced time frame (Conder et al. 2001). Several authors ( $\mathrm{Li}$ et al. 1996; Lin et al. 1998) consider that a more correct approach to the distribution of species in natural environment could be obtained by studying the kinetics of the extraction with a single reagent.

Moreover combination of data from extraction procedures and the PTE quantities that accumulated in plants growing on contaminated sites can provides good information for identifying their input into the environment (Wang et al. 2009; Meers et al. 2005; Fernandez et al. 2002).

The most widely used extractants in single extraction methods include: i) chelating, complexing or reducing agents (such as EDTA and DTPA extractants) which are considered as suitable for the prediction of plant uptake by extracting a large portion or the entire total PTE from the solid phase, ii) acid extractants (such as $0.1 \mathrm{M} \mathrm{HCl}$ because low $\mathrm{pH}$ favors the 
dissociation of the existing complexes) and iii) neutral salt extractants based on un-buffered salt solutions, which mainly dissolve the cation exchangeable fraction (such as $0.01 \mathrm{M} \mathrm{CaCl}_{2}$, $0.1 \mathrm{M} \mathrm{NaNO}$ and $1 \mathrm{M} \mathrm{NH}_{4} \mathrm{NO}_{3}$ ) which are often called 'mild' extractants. ((Ure et al. 1993; Brun et al. 1998; Negrel et al. 2000; Sutherland 2002; McCready et al. 2003; Feng et al. 2005; Gupta and Sinha 2007; Fang et al. 2007; Menzies et al. 2007; Kubova et al. 2008; Black et al. 2011).

The aim of this study was thus to assess the chemical availability and phytoavailibility of PTE, respectively $\mathrm{Zn}, \mathrm{Pb}$ and $\mathrm{Cd}$, in contaminated surface technosols from metallophyte grassland located at (Mortagne-du-Nord, France) and $\mathrm{As}, \mathrm{Pb}$ and $\mathrm{Sb}$ from a former mining site (La Petite Faye, Limoges, France) using various chemical single extraction procedures and germination tests with dwarf beans. Results of the chemical extraction tests were compared with the PTE concentrations of primary dwarf bean leaves and mineral masses in order to gain information about the plant availability and mobility.

\section{Materials and methods}

\subsection{Soil sampling}

Two contaminated Technosols were selected for this study. The first one is metallophyte grassland contaminated with $\mathrm{Zn}, \mathrm{Pb}$ and $\mathrm{Cd}$ located at Mortagne-du-Nord (MDN) in Northern France. This area is adjacent to the former metallurgical site occupied for over 60 years by a $\mathrm{Zn}$ smelter unit linked to a sulfuric acid production unit and a $\mathrm{Pb}$ smelting unit (Thiry and van Oort 1999). The second is a former mine tailing of La Petite Faye (LPF) located $60 \mathrm{~km}$ NorthEast of Limoges (France), where about $35000 \mathrm{t}$ wastes from a former gold mine are stored for over 45 years. These mining wastes were characterized by high total concentrations in PTEs such as As, Pb and Sb. (Néel et al. 2003).

Three locations from each site named (MDN1, MDN2, MDN3) and (LPF1, LPF2, LPF3) respectively, were selected for this study according to the level of PTE concentrations and spatial distribution of the vegetation cover. In the MDN site the vegetation cover essentially consists of Arabidopseshallari and Avena sativa L., whereas, in LPF site, Graminea, Equisetum telmateia, Betulapendula and Pteridiumaquilinum were present with large horsetails of black alder and poplar (Wanat et al. 2014).

Surface soils $(0-20 \mathrm{~cm})$ were sampled from each location with a stainless steel spade. All soil samples collected were carefully transferred to clean polyethylene bags before transport to the laboratory. Collected soil samples were oven-dried at a constant temperature of $40^{\circ} \mathrm{C}$, manually homogenized and then quartered. Two equivalent fractions were obtained from each 
quartered sample. One fraction was used for the determination of the soil physico-chemical properties whereas the other fraction was used for chemical analysis of PTE. Samples for chemical analysis were sieved first using a $2 \mathrm{~mm}$ mesh sieve, to remove gross plant matter and subsequently crushed to pass through a $250 \mu \mathrm{m}$ sieve (Brooks 1983).

\subsection{Reagents and standards}

All the reagents used to prepare the extracting solutions were products of analytical-grade quality (Merck pro-analysis, Darmstadt, Germany). All solutions and dilutions were prepared using doubly deionized water $\left(18.2{\mathrm{M} \Omega \mathrm{cm}^{-1}}^{\text {) }}\right.$ (Thermo Scientific Barnstead Easy pure II systems). Standard stock solutions of $1000 \mathrm{mg} .1^{-1}$ of different elements were prepared from metal wires or salts of purity higher than $99.998 \%$ (VWR international, BDH Prolabo ICP Standards, Belgium). Diluted standard working solutions were prepared from these on a daily basis. All laboratory glassware and plastic ware were rinsed three times with double deionized water after being soaked in a $\mathrm{HNO}_{3}(10 \%$, v/v) batch for $24 \mathrm{~h}$.

\subsection{Aqua regia / hydrofluoric acid digestion}

The Pseudo-total element concentrations were determined by aqua regia / hydrofluoric acid digestion (Zhang et al. 2008). Approximately $1 \mathrm{~g}$ of the sample was accurately weighed into a $100 \mathrm{ml}$ teflon beaker. $20 \mathrm{ml}$ of aqua regia $\left(\mathrm{HNO}_{3}: \mathrm{HCl}, 1: 3 \mathrm{v} / \mathrm{v}\right)$ and $20 \mathrm{~mL}$ of concentrated hydrofluoric acid were added to the beaker. The beaker was then placed on a hot plate that had been adjusted to $130-150^{\circ} \mathrm{C}$. After the solution was evaporated to near dryness, the beaker walls were rinsed with double deionized water and this solution was heated to dryness. One milliliter of concentrated nitric acid and a further $20 \mathrm{ml}$ of double deionized water were added after the beaker was removed from the hot plate and cooled to room temperature. The beaker was heated again on a hot plate at $90-100^{\circ} \mathrm{C}$, most of the sample being digested into solution after $1 \mathrm{~h}$. Cooled to room temperature; the solution was filtered through a $0.45 \mu \mathrm{m}$ cellulose nitrate filter and then diluted to volume with double deionized water in a $100 \mathrm{ml}$ volumetric flask. The PTE concentrations in the solutions were determined by inductively coupled plasma mass spectrometry (ICP-MS, Finnigan Element XR,Thermo Electron, Germany). Blank extractions (without sample) were carried out throughout the complete procedure.

\subsection{Single extraction methods}

Two categories of extractants were used in this study: (i) $\mathrm{CaCl}_{2}, \mathrm{NaNO}_{3}$ and $\mathrm{NH}_{4} \mathrm{NO}_{3}$ as salts or cationic exchange extractants and (ii) EDTA and DTPA as chelating or reducing agents. 
For $\mathrm{CaCl}_{2}$ extraction, $10 \mathrm{ml}$ of $0.01 \mathrm{M} \mathrm{CaCl} 2$ were added to $1.0 \mathrm{~g}$ of soil in a $25 \mathrm{ml}$ polypropylene centrifugation tube for each soil sample, shaken for $2 \mathrm{~h}$ at $20^{\circ} \mathrm{C}$ (Uzu et al. 2009). The liquid to solid ratio of 10 is high enough to avoid sample heterogeneities (Houba et al. 1996). For $\mathrm{NaNO}_{3}, 20 \mathrm{ml}$ of $0.1 \mathrm{M} \mathrm{NaNO}$ were added to $8.0 \mathrm{~g}$ of air-dry soil, shaken for $2 \mathrm{~h}$ at $20^{\circ} \mathrm{C}$ (Gupta and Aten 1993). For $\mathrm{NH}_{4} \mathrm{NO}_{3}$ extraction, in $100 \mathrm{ml}$ polypropylene centrifugation tube, $50 \mathrm{ml}$ of $1 \mathrm{M} \mathrm{NH}_{4} \mathrm{NO}_{3}$ were added to $10 \mathrm{~g}$ of air-dry soil, shaken for $2 \mathrm{~h}$ at $20^{\circ} \mathrm{C}$ (Gupta and Sinha 2007). In the case of EDTA extraction, $25 \mathrm{ml}$ of $0.05 \mathrm{M}$ EDTA were added to $5.0 \mathrm{~g}$ of air-dry soil, shaken for $1 \mathrm{~h}$ at $20^{\circ} \mathrm{C}$ (Quevauviller et al. 1997). For DTPA extraction, $20 \mathrm{ml}$ of extractant consists of $0.005 \mathrm{M}$ DTPA (diethylenetriaminepentaacetic acid), $0.1 \mathrm{M}$ triethanolamine, and $0.01 \mathrm{M} \mathrm{CaCl}_{2}$, with a $\mathrm{pH}$ of 7.3 were added to $10 \mathrm{~g}$ of air-dry soil, shaken for $2 \mathrm{~h}$ at $20^{\circ} \mathrm{C}$ (Lindsay and Norvell 1978). For all above procedures, after agitation, samples were subsequently centrifuged and the samples were filtered through a $0.45 \mu \mathrm{m}$ filter paper then acidified with a few drops of concentrated $\mathrm{HNO}_{3}$ to prevent adsorption to the polyethylene of the storage vessel. The acidified supernatant was collected in polyethylene bottles and stored at $4^{\circ} \mathrm{C}$ until analysis. PTE concentrations were determined by ICP-MS (Finnigan Element XR, Thermo Electron, Germany). Five replicates were performed for each sample and each procedure. Blanks from extracting reagents described above were measured in parallel for each batch of analysis. ICP-MS measurements were carried out by diluting 1:10 $\mathrm{CaCl}_{2}, \mathrm{NaNO}, \mathrm{NH}_{4} \mathrm{NO}_{3}$, EDTA and DTPA extracts (in 1\% $\mathrm{HNO}_{3}$ ) to minimize interferences from calcium and sodium present in the extracts (Vaughan et al. 1986).

\subsection{Germination tests}

Pot experiments were conducted with contaminated technosols from the MDN and LPF sites. Approximately $1 \mathrm{~kg}$ of soil for each sub-location was potted in plastic plant pots after homogenizing and sieving the soil to pass a $2 \mathrm{~mm}$ mesh. 4 seeds of dwarf bean were sown in each pots and cultivated for 21 days in controlled conditions (16h light/8h darkness regime, $25^{\circ} \mathrm{C} / 21^{\circ} \mathrm{C}$ ). The photoperiod was set at $16 \mathrm{~h}$ day with an approximate photon flux of $150 \mu \mathrm{E}$ $\mathrm{m}^{-2} \mathrm{~s}^{-1}$. The soil water holding capacity was kept between $55 \%$ and $65 \%$ of the potential water holding capacity by daily measuring weight of each pot. It was adjusted with deionized water throughout the experimental period.

\subsection{Plant analysis}

Plants were harvested 21 days after sowing, the above ground plant tissues (primary leaves) were cut and rinsed thoroughly with double deionized water. Washed leaves were dried at 
$80^{\circ} \mathrm{C}$ for $72 \mathrm{~h}$ before recording the dry matter yield. Dried plant leaves were ground with a laboratory grinder and digested with a pressurized closed-vessel microwave system (Multiwave 3000, Anton Paar GmbH, Germany). Microwave polyfluoroacetylene (PFA)teflon vessels were cleaned before each digestion using $10 \mathrm{ml}$ of aqua regia $\left(\mathrm{HNO}_{3} / \mathrm{HCl}\right.$, $1: 3 \mathrm{v} / \mathrm{v}$ ), heated for $20 \mathrm{~min}$. at $200^{\circ} \mathrm{C}$ and then rinsed with double deionized water. After the microwave-assisted digestion procedure was optimized, the following conditions were employed: samples were accurately weighed to $200 \mathrm{mg}( \pm 0.1 \mathrm{mg})$ in microwave vessels. The digestion program consisted of a $15 \mathrm{~min}$ gradual increase to $200^{\circ} \mathrm{C}$, a $15 \mathrm{~min}$ digestion step at $200^{\circ} \mathrm{C}$ and $1200 \mathrm{w}$ and then a cooling stage. After cooling to room temperature, the samples were filtered through a $0.45 \mu \mathrm{m}$ filter paper and diluted to $50 \mathrm{ml}$ with ultra-pure water (18 $\left.\mathrm{M} \Omega \mathrm{cm}^{-1}\right)$. Blanks were processed in a method identical to the samples. ICP-MS measurements were carried out by diluting 1:10 the plant digests to determine the primary dwarf bean leaves PTE concentrations. Mineral masses of PTE related to one dwarf bean were calculated based on the bean dry weight and PTE concentration in the bean leaves.

\subsection{Statistical analysis}

All tests were performed in five replicates and results are presented as mean \pm standard deviation. The data were statistically analyzed using Excel and Statistica 10 package software. Statistical analysis including Pearson's correlation coefficient were calculated to determine the relationships between the PTE concentrations in the above parts of dwarf bean (primary leaves), the PTE mineral masses and extractable PTE concentrations in soils by the various single extraction methods. The correlations were examined based on plant concentrations on dry weight (DW) basis. The level of significance was set at $(\mathrm{p}<0.05)$.

\section{Results and discussion}

\subsection{Physico-chemical properties of the studied soils}

The main physico- chemical properties of the soil samples are summarized in Table 1. $\mathrm{pH}$ of MDN samples was slightly acid and ranged from 6.14 to 6.92, whilst, $\mathrm{pH}$ of LPF samples was acidic to slightly acid ranged from 3.65 to 5.75. Organic carbon ranged from 3.35 to $6.45 \%$ and 0.3 to $1.67 \%$ for both MDN and LPF samples respectively. Cation exchange capacity varied from 6.7 to $8.5 \mathrm{cmol}(+) \mathrm{kg}^{-1}$ and 18.3 to $39.7 \mathrm{cmol}(+) \mathrm{kg}^{-1}$ for MDN and LPF respectively. Pseudo total PTE contents for both MDN and LPF soil samples are presented in Table 2. 


\subsection{PTE extractability}

The results of $\mathrm{Zn}, \mathrm{Cd}, \mathrm{Pb}, \mathrm{As}$ and $\mathrm{Sb}$ extractabilities in $\mathrm{mg} \cdot \mathrm{kg}^{-1}$ obtained with the five extraction procedures on the studied polluted samples are presented in Table 3 and Table 4 for the MDN and LPF samples respectively. To help compare the metals extracted by different methods, the relative metals extractabilities expressed in percent are presented in Fig. 1. The $\mathrm{CaCl}_{2}, \mathrm{NaNO}_{3}, \mathrm{NH}_{4} \mathrm{NO}_{3}, \mathrm{EDTA}$ and DTPA soil extractable fractions were different from sample to sample for both studied sites.

The highest extracted amounts of $\mathrm{Zn}$ were observed for the highly contaminated soil (MDN1). Zn extractability obtained with the EDTA extraction was higher compared with that obtained with the DTPA and the other extraction procedures for all MDN selected locations. The extracted $\mathrm{Zn}$ decreased successively for extraction with DTPA to $\mathrm{NaNO}_{3}$, but exhibited a significantly higher extracted amount for the EDTA solution. $\mathrm{NaNO}_{3}$ exhibits the lowest extraction efficiency in all samples. Overall, the sequence of $\mathrm{Zn}$ extractability in all studied samples being: EDTA $>$ DTPA $>\mathrm{NH}_{4} \mathrm{NO}_{3}>\mathrm{CaCl}_{2}>\mathrm{NaNO}_{3}$, except, for MDN2, extractable-Zn was found higher with $\mathrm{CaCl}_{2}$ than that of $\mathrm{NH}_{4} \mathrm{NO}_{3}$. It can be seen that dilute $\mathrm{CaCl}_{2}$ and nitrate extracting media does not extract high amount of PTE as compared to the complexing extracting media such as EDTA. These results are in concordance with previous studies, where EDTA was found the best extractant for phytoavailability of metals and solubilizes solid phase minerals giving a potential to over-estimate the bioavailable fraction of metals in soils (Singh, 2007). McLaughlin et al. (2000) also suggested that complexing extractants may provide a better estimate of potential hazards from future mobilization of metals than neutral salt extractions.

Similarly to $\mathrm{Zn}$, the highest amount of extracted Cd was also observed for MDN1 with the EDTA extract. The amount of Cd extracted with EDTA and DTPA procedures was always higher than with the other solutions, the sequence of extractability in all samples being: EDTA $>$ DTPA $>\mathrm{CaCl}_{2}>\mathrm{NH}_{4} \mathrm{NO}_{3}>\mathrm{NaNO}_{3}$. Gupta and Sinha (2007) also reported that the complexing agents such as EDTA and DTPA were extracted higher Cd content in tannery waste contaminated soil. Indeed, in a comparison of the effectiveness of the neutral salt solutions, $\mathrm{NH}_{4} \mathrm{NO}_{3}$ extractability was in general higher than that obtained with $\mathrm{CaCl}_{2}$ and $\mathrm{NaNO}_{3}$. For $\mathrm{MDN} 2$, the extraction efficiency $\left(\mathrm{CaCl}_{2}>\mathrm{NH}_{4} \mathrm{NO}_{3}\right)$ for both $\mathrm{Cd}$ and $\mathrm{Zn}$ is consistent with previous findings of Novozamskyet al. (1993); Száková et al. (2001) and Pueyo et al. (2004) which that due to the combined effect of complexation by chloride, $\mathrm{CaCl}_{2}$ in some soils can extract a higher metal amount than that by $\mathrm{NH}_{4} \mathrm{NO}_{3}$.

For $\mathrm{Pb}$, similar extraction efficiencies for all studied samples were obtained. Again, the extractability with EDTA was higher in comparison with the other extractants. In contrast to 
the EDTA, other methods yielded 10 times lower extracted amounts. The extraction efficiency in all samples decreased with the order: EDTA $>$ DTPA $>\mathrm{NH}_{4} \mathrm{NO}_{3}>\mathrm{CaCl}_{2}>\mathrm{NaNO}_{3}$. This result is consistent with the findings of Menzies et al. (2007); Gupta and Sinha (2007). Due to fact that many precipitation processes (e.g. hydroxides, carbonate and phosphates) affect the $\mathrm{Pb}$ extract content in soils, Lebourg et al. (1998b) referred to that these processes are limiting the estimation of lead bioavailability in soils by using the mild extraction solutions. In recent study, Gupta and Aten, (1993); Hornburg et al. (1995) have also referred to that the using of these extraction procedures have exhibits low $\mathrm{Pb}$ extractability.

Among all the extractants, EDTA extraction showed the better extractability of As and Sb in all the tested contaminated soil samples. Overall, extraction capacity was as follows: EDTA $>$ DTPA $>\mathrm{NH}_{4} \mathrm{NO}_{3}>\mathrm{CaCl}_{2}>\mathrm{NaNO}_{3}$. These results are consistent with that reported by Etteler et al. (2007a). It can be seen from the results, the concentration of the EDTAextractable $\mathrm{Sb}$ was in the range of $11.1-11.8 \%$. These results are relatively similar to that reported by He (2007) and Serafimovska et al. (2012) for the phytoavailable fraction (2.1 $11.8 \%$ ) of $\mathrm{Sb}$ in contaminated soils. The relatively high phytoavailable As and $\mathrm{Sb}$ can represent a significant proportion in highly contaminated soils, but actual uptake will depend on plant species (Pérez-Sirvent et al. 2011).

In this study, it can be observed that neither dilute $\mathrm{CaCl}_{2}$ extracting media nor nitrate solutions extract very high amount of elements as compared to EDTA and to total metal contents especially for LPF metals $\mathrm{As}, \mathrm{Pb}$ and $\mathrm{Sb}$. On the other hand, $\mathrm{Zn}, \mathrm{Pb}$ and $\mathrm{Cd}$ in MDN site showed a better extractability in comparison to both total content and to LPF site metals. This is due to the fact that LPF site PTE were strongly associated with the residual fraction in all studied samples, whereas, a good percentage of PTE in the MDN site were found to associated with acid soluble fraction (Qasim and Motelica-Heino, 2014). This findings matched with that of (Lintschinger et al. 1998; Tighe et al. 2005; Denys et al. 2008; Wanat et al. 2013; 2014) which the low soluble contents can be explained by the association of As and $\mathrm{Sb}$ to stable phases, as iron oxides and residual fraction.

\subsection{Evaluation of single extraction efficiency}

From the results obtained during our work (Table 3 and Table 4) it can be seen that the EDTA was found to be the most efficient solution due to extract both carbonate and organically bound fractions of PTE which may be due to its low pH (Sahuquillo et al. 2003). EDTA extractants use organic ligands capable of forming strong complexes with metals as the basis of the extraction process (Menzies et al. 2007). Moreover, Dermont et al. (2008b) in 
reviewing soil washing for metal removal, considers that EDTA is effective because it is recoverable and reusable (low biodegradability).

DTPA was also found to be an efficient extraction solution for soils with $\mathrm{pH}>5$ to neutral $\mathrm{pH}$ conditions, but it exhibits low efficient in highly acidic soil for some PTE (in the case of As), where DTPA extracted amounts significantly lower than that of other extractants. This is probably due to the re-adsorption of negatively charged metal-DTPA complexes. Furthermore, Norvell (1984) and Ettler et al. (2007b) also reported that the pH buffering capacity of the DTPA method fails in some highly acidic soils.

In general, complexing agents form soluble complexes with metals in solution, thus reducing their activity and causing additional metal ions to desorb from the soil (Singh, 2007). Moreover, complexing agents are aggressive and solubilize solid phase minerals giving a potential to over-estimate the bioavailable fraction of metals in soils.

Besides, the $\mathrm{NH}_{4} \mathrm{NO}_{3}$ extraction solution yielded higher values for the extracted concentrations for all the studied PTE than that of $\mathrm{CaCl}_{2}$, except for $\mathrm{As}$ and $\mathrm{Sb}$ in some soils. Lebourg et al. (1998a); Pueyo et al. (2004) referred to that the high Cd and $\mathrm{Zn}$ extractability obtained with the $\mathrm{NH}_{4} \mathrm{NO}_{3}$ procedure in comparison with the other neutral salt solutions might be due to the higher salt concentration of the $\mathrm{NH}_{4} \mathrm{NO}_{3}$ solution and the possible complexation of these elements by $\mathrm{NH}_{3}$.

The use of neutral salt solution such as $\mathrm{CaCl}_{2}$ solution as extractant is advocated on the assumption that phytoavailable PTE are mostly located on mineral surfaces and can be displaced by other cations (Meers et al. 2007a). Hornburg et al. (1995); Lopez-Sanchez et al. (2002) referred to that as due to the combined effect of complexation by chloride; $\mathrm{CaCl}_{2}$ can extract higher amounts of both $\mathrm{Zn}$ and $\mathrm{Cd}$ than the other neutral extractants. Also, van der Sloot et al. (1996) reported that the divalent cation $\mathrm{Ca}^{2+}$ can remove them more easily than monovalent cations, such as $\mathrm{Na}^{+}$and $\mathrm{NH}_{4}{ }^{+}$by the fact that these elements are adsorbed in cation-exchange positions.

Weak salts are favored because of their role in releasing elements from particular soil phases with which they are bound or associated especially $\mathrm{CaCl}_{2}$. The use of $\mathrm{CaCl}_{2}$ solution in this experiment might be due to that several studies have shown its ability to predict soil-solution concentrations for metals (e.g. Cd, $\mathrm{Zn}$ ), and also, the extracted metals are not re-adsorbed on the solid soil constituents during the extraction, which are present in the extracts as free ionic forms or positively charged chloro-complexes (Pueyo et al. 2004; Meers et al. 2007b; Ettler et al. 2007b). 


\subsection{PTE bioavailability}

The pot experiment of dwarf beans grown in both MDN and LPF soils for 21 days showed an accumulation of varying amounts of PTE in the plant primary leaves. Among all tested elements, the accumulation of $\mathrm{Zn}$ was found maximum, whereas, $\mathrm{Sb}$ was found to be minimum in the plant leaves. On average, the total areal biomass after 21 days varied between 0.06 and $0.16 \mathrm{~g} / \mathrm{plant}$ dry weight. In the present study, the range and distribution of observed primary leaves concentrations for all PTE were broad (Table 5).

In general, dwarf bean plants growing in the MDN soils were found to have high $\mathrm{Zn}$ concentration $\left(240\right.$ - 372 mg.kg $\left.{ }^{-1} \mathrm{DW}\right)$. Foliar Zn concentration in MDN1 plants was 1.5 times higher compared to both MDN2 and MDN3. The bean leaves presented Zn levels generally above the considered normal levels of $\mathrm{Zn}$ in plant tissues (10 to $100 \mathrm{mg} \mathrm{kg}^{-1}$ ) according to Frisberg et al. (1986), which may indicate that these plant species growing on the contaminated site were tolerant to $\mathrm{Zn}$. The high level of $\mathrm{Zn}$ concentrations in bean leaves may be due to the fact that $\mathrm{Zn}$ have a high mobility, and particularly in the $\mathrm{Zn}$-rich soils, $\mathrm{Zn}$ might be translocate from the plant roots (which contain high $\mathrm{Zn}$ levels) and accumulated in the top parts of the plant.

Foliar Cd concentrations varied from $3.12-6.30 \mathrm{mg} \cdot \mathrm{kg}^{-1} \mathrm{DW}$, this value being much higher than that reported by Feeney et al. 1984 in bean $\left(0.13 \mathrm{mg} \cdot \mathrm{kg}^{-1}\right)$ and MacLean 1976 (0.29 mg. $\left.\mathrm{kg}^{-1}\right)$. A foliar cadmium concentration in plants from uncontaminated soils was about 0.044 mg.kg ${ }^{-1}$ (Hattab 2013). The long-term availability of $\mathrm{Cd}$ in plants is related to several soil properties, the presence of other ions in the soil solution, and the plant species. Due to the competition of $\mathrm{Zn}$ and $\mathrm{Cd}$ for -SH groups of proteins and enzymes in plants, Chaney (1974) proposed that zinc-cadmium interactions reduce the amount of $\mathrm{Cd}$ taken up by plants when the concentration of $\mathrm{Cd}$ is less than $1 \%$ of the zinc content in the sludge.

Foliar $\mathrm{Pb}$ concentrations ranged between $\left(16-29 \mathrm{mg} \cdot \mathrm{kg}^{-1}\right)$ and $\left(5.7-8.6 \mathrm{mg} \cdot \mathrm{kg}^{-1} \mathrm{DW}\right)$ in both MDN and LPF soils respectively and were above the mean lead content in bean as reported by Theodoratos et al. (2002) $\left(0.1-5 \mathrm{mg} \cdot \mathrm{kg}^{-1} \mathrm{DW}\right)$. Foliar As and Sb concentrations in bean leaves were ranged from $\left(46-72 \mathrm{mg} \cdot \mathrm{kg}^{-1}\right)$ and $\left(1.48-1.52 \mathrm{mg} . \mathrm{kg}^{-1}\right)$ respectively. Concentrations of As in plants grown on uncontaminated soils vary from 0.009 to $1.5 \mathrm{mg} . \mathrm{kg}$ 1DW, (Kabata- Pendias and Pendias, 2000). It has also been reported that foliar As concentrations $\left(\mathrm{mg} \mathrm{As} \mathrm{kg}^{-1}\right)$ described in beans grown on control soils were $5.2 \pm 0.2$ (Carbonell-Barrachina et al., 1997), 0.38 (Mench et al. 2006), and 1- 4 (Macnicol and Beckett, 1985). In this study foliar As concentrations were many times higher than those reported by above studies. Overall, the total PTE accumulation was following the order: $\mathrm{Zn}>\mathrm{As}>\mathrm{Pb}>\mathrm{Cd}>\mathrm{Sb}$. Meers et al. (2007b) also reported that high concentration of $\mathrm{Zn}$ was 
accumulated in the aerial parts of Phaseolus vulgaris grown in different soil textures in comparison to other metals such as $\mathrm{Cd}, \mathrm{Cu}, \mathrm{Pb}$ and $\mathrm{Mn}$. Wanat et al. (2014) showed that $\mathrm{As}$ concentrations in various organs of plants from the natural vegetation cover were much higher than that of both $\mathrm{Pb}$ and $\mathrm{Sb}$.

Liphadzi and Kirkham (2005); Gupta and Sinha (2007a) shown that the process of metal accumulation in plants depends on the concentration of available metals in soils and their mobility and the plant species growing on these soils. The PTE considered readily available for plant uptake are those that exist as soluble components in the soil solution or that are easily desorbed or solubilized by root exudates, representing often only a small portion of the total content of the soil (Blaylock and Huang, 2000), as was found in the present study.

For MDN site, foliar $\mathrm{Zn}, \mathrm{Pb}$ and $\mathrm{Cd}$ mass varied from (25.2 to 59.5), (1.68 to 4.64) and (0.32 to 1.008) $\mathrm{mg}$ per plant respectively (Fig. 2a, b, c). Moreover, for LPF site, foliar As, Pb and Sb mass varied from (3.34 to 5.08$)$, (0.53 to 0.57$)$ and (0.08 to 0.12$) \mathrm{mg}$ per plant respectively (Fig. 2d, e, f).

\subsection{Correlation of soil single extraction and bioavailability}

Results of the Pearson's correlation tests used to establish possible relationships between the extractable PTE contents and the concentration of PTE measured in dwarf bean primary leaves and foliar PTE mass are presented in Table 6 and Table 7 respectively. EDTA and DTPA represented the highest $\mathrm{Zn}$ extractability (Table 3), while they have present a poor prediction of $\mathrm{Zn}$ phytoavailibility for both foliar $\mathrm{Zn}$ concentrations and foliar $\mathrm{Zn}$ mass. In contrast, the other extractions based on diluted chloride solution $0.01 \mathrm{M} \mathrm{CaCl}_{2}$ and nitrate solutions $\mathrm{NaNO}_{3}$ and $\mathrm{NH}_{4} \mathrm{NO}_{3}$ provided significant positive correlations $(P<0.05)$ with $\mathrm{Zn}$ accumulation and foliar $\mathrm{Zn}$ mass. These results correspond to those reporting that neutral salt solutions are more effective in estimating plant availability than the more aggressive tests such as EDTA and DTPA (Gupta and Aten, 1993; Lebourg et al., 1996; Sauerbeck and Styperek, 1985). Sauerbeck and Styperek (1983) also observed that the neutral salt solution is a useful extractant to predict the availability of trace metals in soil, and to be a good predictor of $\mathrm{Zn}$ in green beans (Houba et al. 1990).

In the case of $\mathrm{Cd}$, although both EDTA and DTPA exhibited the highest Cd extractability in comparison to other neutral solutions; neither EDTA nor DTPA exhibited significant correlations with $\mathrm{Cd}$ levels in plant leaves and foliar mass. The best predictors for accumulated $\mathrm{Cd}$ and $\mathrm{Cd}$ mass were found with the results of unbuffered salt solutions $\mathrm{CaCl}_{2}$, $\mathrm{NaNO}_{3}$ and $\mathrm{NH}_{4} \mathrm{NO}_{3}$. Again, these weak extraction procedures were all correlated 
significantly $(P<0.05)$ with bean leaves Cd accumulation. Krishnamurti et al. (2000) found that EDTA provided the poorest prediction of $\mathrm{Cd}$ availability. This apparent conflict in the reported effectiveness of complexing extractants may be due, at least partially, to differences between studies in the soils organic matter content, soil $\mathrm{pH}$, the amount, source and form of the metal contaminant, and also the age of contaminant. Whitten and Richie (1991); Novozamsky et al. (1992) also reported a good correlation between extracted Cd by $0.01 \mathrm{M}$ $\mathrm{CaCl}_{2}$ and accumulated $\mathrm{Cd}$ in subterranean clover, lettuce and endive plants. Smild et al. (1992) also found high correlations between $\mathrm{CaCl}_{2}$ extractable $\mathrm{Zn}$ and $\mathrm{Cd}$ and their concentrations in maize plant.

In a comparison of the effectiveness of the five different extractants for the prediction of $\mathrm{Cd}$ availability, Novozamsky et al. (1993) proposed using of $0.01 \mathrm{M} \mathrm{CaCl}_{2}$ as extraction reagent for estimation of metals and nutrients in air dry soil samples.

All the five extraction procedures showed significant correlations $(P<0.05)$ with accumulated $\mathrm{Pb}$ in dwarf bean leaves for both MDN and LPF soils but not for foliar Pb mass in LPF samples. Similar to findings for both $\mathrm{Zn}$ and $\mathrm{Cd}$, the weaker extractions based on neutral salt solutions exhibited the best correlations between chemical extractions and plant PTE accumulation but not for $\mathrm{Pb}$ mass in LPF site. Even if many authors (Baxter et al. 1983; Cajuste et al. 2000; Miner et al. 1997; Sistani et al. 1995) concluded that complexing reagents give poor correlation to plant uptake, Gupta and Sinha (2007) reported that EDTA has shown best correlation with metals accumulated in the Sesamum indicum grown on different amendment of tannery sludge. Meers et al. (2007b) also found significant interactions of DTPA extractable $\mathrm{Pb}$ with plant uptake in the assessment of metals phytoavailibility.

In the current data set, good correlations were also observed between bean leaves accumulation and weaker extractants based on neutral salt solutions $\left(\mathrm{CaCl}_{2}, \mathrm{NaNO}_{3}\right.$ and $\mathrm{NH}_{4} \mathrm{NO}_{3}$ ) and extractable As. Again, neither EDTA nor DTPA extraction procedures, aimed at ascertaining soil solution levels yielded consistently significant correlations with plant uptake and foliar As mass. These results are in accordance with findings of Martínez-Sánchez et al. (2011).

In contrast to $\mathrm{As}, \mathrm{NaNO}_{3}$ did not exhibit a significant correlation in the case of $\mathrm{Sb}$, whilst, $\mathrm{CaCl}_{2}$ and $\mathrm{NH}_{4} \mathrm{NO}_{3}$ presented positive significant correlation between extractable $\mathrm{Sb}$ and its level in the dwarf bean leaves and foliar Sb mass. In comparison to complexing agent, the extraction carried out with DTPA and EDTA cannot be considered appropriate for studying $\mathrm{Sb}$ mobility since they were not well correlated with plant $\mathrm{Sb}$ accumulation.

In general, distinct differences can be observed for the various PTE as significant correlations between the extraction procedures and PTE accumulation in the dwarf bean leaves in both 
MDN and LPF samples. For all studied PTE the weaker extractants based on neutral salt solution exhibited good correlations with the PTE plant content. Except for $\mathrm{Pb}$, the complexing agents resulted in higher correlations. The best correlation was that of $0.01 \mathrm{M}$ $\mathrm{CaCl}_{2}$ in all studied samples. An important advantage is that the ionic strength of this extraction solution is similar to that of soil solution. In addition, $\mathrm{Ca}$ is generally the most abundant cation present in the soil solution.

\section{Conclusion}

Different extractants were used to evaluate the best extractant for bioavailability of metals to dwarf bean leaves in two former mining and smelting Technosols. The highest PTE ( $\mathrm{Zn}, \mathrm{Cd}$, $\mathrm{Pb}, \mathrm{As}$ and $\mathrm{Sb}$ ) extractabilities were observed for the EDTA solution whereas other extraction media yielded lower extractabilities in comparison to EDTA. The results of Pearson's correlation coefficient analysis showed significant positive correlations between PTE accumulation in bean leaves and extractable metals by the neutral solutions $\left(\mathrm{CaCl}_{2}, \mathrm{NaNO}_{3}\right.$ and $\mathrm{NH}_{4} \mathrm{NO}_{3}$ ). Poor correlation was found with both EDTA and DTPA extractable metals, except for $\mathrm{Pb}$ in both studied sites. In MDN site, $\mathrm{Zn}, \mathrm{Pb}$ and $\mathrm{Cd}$ can be considered the most mobile elements and potentially available to the biosphere, representing therefore a more significant environmental risk than $\mathrm{Pb}, \mathrm{Sb}$ and $\mathrm{As}$ in $\mathrm{LPF}$ samples.

In general, the $\mathrm{CaCl}_{2}$ extraction procedure proved to be a suitable method for the assessing of metal mobility in soils and as it provided a good indication of phytoavailability of all metals under investigation. In accordance with other findings (Novozamsky et al. 1993; Pueyo et al. 2004; Meers et al. 2007b), the use of this procedure is therefore supported for evaluation of plant available PTE in the soil. In investigations dealing with soil ecosystems, it is necessary to take into consideration the content of soluble forms of metals in the soil solution, i.e. susceptible to transfer to the trophic chain, irrespective of the total PTE content.

\section{Acknowledgements}

The authors wish to acknowledge the Ministry of Higher Education and Scientific Research (Baghdad, Iraq) for financial support, Dr. Domenico Morabito (Université d'Orléans) for microwave digestion and Dr. Cécile Grosbois (Université de Tours) for granulometric analysis. 


\section{References}

Abollino O, Aceto M, Malandrino M, Mentasti E, Sarzanini C, Barberis R (2002) Distribution and mobility of metals in contaminated sites. Chemometric investigation of polluant profiles. Environ Pollut 119:177-193

Afnor 1999 Recueil de Normes Françaises. Qualité des sols. Afnor, Paris.

Anjos C, Magalhaes MCF, Abreu MM (2012) Metal (Al, Mn, Pb and Zn) soils extractable reagents for available fraction assessment: comparison using plants, and dry and moist soils from the Bracal abandoned lead mine area, Portugal J Geochem Explor 113:45-55

Black A, McLaren RG, Reichman SM, Speir TW, Condron LM (2011) Evaluation of soil metal bioavailability estimates using two plant species (L. perenne and T.aestivum) grown in arrange of agricultural soils treated with biosolids and metalsalts. Environ Pollut 159:1523-1535

Brown GE, Calas G (2011) Environmental mineralogy - understanding element behavior in ecosystems. C R Geoscience 343:90-112

Chaney RL (1975) Recommendation for management of potent1ally toxic elements in agriculture and municipal wastes. In: Factors involved in land application of agricultural and municipal Wastes. Agriculture Research Service USA. pp. 97-120.

Chojnacka K, Chojnacki A, Gorecka H, Gorecki H (2005) Bioavailability of heavy metals from polluted soils to plants. Sci Total Environ 337:175-182

Conder JM, Lanno RP, Basta NT (2001) Assessment of metal availability in smelter soils using earthworms and chemical extractions. J Environ Qual 30:1231-1237

Cornu S, Clozel B (2000) Extractions séquentielles et spéciation des éléments trace métalliques dans les sols naturels. Analyse critique. In : Etude et Gestion des sols, vol 7, 3rd ed., 179-189.

Ettler V, Mihaljevic M, Sebek O, Grygar T (2007b) Assessment of single extractions for the determination of mobile forms of metals in highly polluted soils and sedimentsAnalytical and thermodynamic approaches. Analytica Chimica Acta 602:131-140

Ettler V, Mihaljevic M, Sebek O, Nechutny Z (2007) Antimony availability in highly polluted soils and sediments - A comparison of single extractions. Chemosphere 68:455-463

Fangueiroa D, Bermonda A, Santosb E, Carapuçab H, Duarteb A (2002) Heavy metal mobility assessment in sediments basedon a kinetic approach of the EDTA extraction: search for optimal experimental conditions. Analytica Chimica Acta 459:245-256

Feeney S, Peterson J R, Zenz DR, Lue-Hing C (1984) National Survey of the Metals Content of Seven Vegetable Species. Dept. of Research and Development-Report No. 84-4 Metropolitan Sanitary District of Greater Chicago, Chicago, Illinois.

Feng MH, Shan XQ, Zhang SZ, Wen B (2005) Comparison of a rhizosphere-based method with other one-step extraction methods for assessing the bioavailability of soil metals to wheat. Chemosphere 59:939-949 
Fernandez JA, Cerballeria A (2002) Biomonitoring metal deposition in Galicia (NW Spain) with mosses: factors affecting bioconcentration. Chemosphere 46:535-542

Friberg L, Nordberg GR, Vouk VB. 1986. Handbook on the toxicology of metals. New York, NY: Elsevier North Holland, 630.

Gupta AK, Sinha S (2007) Assessment of single extraction methods for the prediction of bioavailability of metals to Brassica juncea L. Czern. (var. Vaibhav) grown on tannery waste contaminated soil. Journal of Hazardous Materials 149:144-150

Gupta AK, Sinha S (2007a) Phytoextraction capacity of plants growing on tannery sludge dumping sites. Biores Technol 98:1788-1794

Gupta SK, Aten C (1993) Comparison and evaluation of extraction media and their suitability in a simple model to predict the biological relevance of heavy metal concentrations in contaminated soils. Int J Environ Anal Chem 51:25-46

Gupta SK, Aten C (1993) Overview of the use of leaching/extraction tests for risk assessment of trace metals in contaminated soils and sediments. Int J Environ Anal Chem 51:25-46

He M (2007) Distribution and phytoavailibility of antimony at an antimony mining and smelting area. Human China Environ Geochem Health 29:209 - 219

He ZL, Yanga XE, Stoffellab PJ (2005) Trace elements in agroecosystems and impacts on the environment. Review J Trace Elem Med Biol 19:125-140

Hornburg V, Welp G, Brümmer GW (1995) Behavior of heavy metals in soils. Extraction of mobile heavy metals using $\mathrm{CaCl}_{2}$ and $\mathrm{NH}_{4} \mathrm{NO}_{3}$. Z Pflanzenernähr Bodenk158:137-145

Houba VJG, Lexmond TM, Novozamsky I,Van Der Lee JJ (1996) State of the art and future developments in soil analysis for bioavailability assessment. Sci Total Environ 178:2128

Houba VJG, Novozamsky I, Lexmond ThM, Van der Lee JJ (1991) Applicability of 0.01 M $\mathrm{CaCl} 2$ as a single extractant for the assessment of the nutrient status of soils and other diagnostic purposes. Commun Soil Sci Plant Anal 23:2029- 2051

ISO 11074 (2005) Soil Quality - Vocabulary International Organisation for Standardisation, International Organisation for Standardisation.

ISO 1999 Soil Quality. Guidance on the ecotoxicological characterisation of soils and soil materials. Guidelines no ISO TC 190/SC 7 ISO/DIS 15799. ISO, Geneva, Switzerland

Kubova J, Matus P, Bujdos M, Hagarova I, Medved J (2008) Utilization of optimized BCR three-step sequential and dilute $\mathrm{HCl}$ single extraction procedures for soil-plant metal transfer predictions in contaminated lands. Talanta 75:1110-1122

Lebourg A, Sterckeman T, Ciesielski H, Proix N (1996) Intérêt de différents réactifs d'extraction chimique pour l'évaluation de la biodisponibilité des métaux en traces du sol. Agronomie 16:201-215 
Lebourg A, Sterckeman T, Ciesielski H, Proix N (1998) Trace metal speciation in three unbuffered salt solutions used to assess their bioavailability in soil. J Environ Qual $27: 584-590$

Lebourg A, Sterckeman T, Ciesielski H, Proix N, Gomez A (1998) Estimation of soil trace metal bioavailability using unbuffered salt solutions: degree of saturation of polluted soil extracts. Environmental Technology 19:243-252

Li Z, Shuman LM (1996) Extractability of zinc, cadmium and nickel in soils amended with EDTA. J Soil Sci 161:226 - 232

Lindsay WL, Norvell WA (1978) Development of a DTPA soil test for zinc, iron, manganese, and copper. Soil Sci Soc Am J 42:421-428

Lopez-Sanchez JF, Sahuquillo A, Rauret G, Lachica M, Barahona E, Gomez A, Ure AM, Muntau H, Quevauviller Ph (2002) Extraction Procedures for Soil analysis. In: Quevauviller P. (ed.) Methodologies for Soil and Sediment fractionation. The Royal Society of Chemistry Cambridge pp 28

Vaughan MA, Horlick G (1986) Oxide, Hydroxide, and Doubly Charged Analyte Species in Inductively Coupled Plasma/Mass Spectrometry. Applied Spectroscopy 40:434-445

Martínez-Sánchez MJ, Martínez-López S, García-Lorenzo ML, Martínez-Martínez LB, PérezSirvent C (2011) Evaluation of arsenic in soils and plant uptake using various chemical extraction methods in soils affected by old mining activities. Geoderma 160:535-541

Liphadzi MS, Kirkham MB (2005) Phytoremediation of soil contaminated with heavy metals: a technology for rehabilitation of the environment. S Afr J Bot 71:24-37

MacLean AJ (1976) Cadmium in different plant species and its availability in soils as influenced by organic matter and addition of lime, P, Cd and Zn. Can J Soil Sci 56:129_ 138

McBride MB, Nibarger EA, Richards BK, Steenhuis T (2003) Trace metal accumulation by red clover grown on sewage sludge amended soils and correlation to Mehlich 3 and calcium chloride-extractable metals. Soil Sci 168:29-38

McCready S, Birch GF, Taylor SE (2003) Extraction of heavy metals in Sydney habour sediments using $1 \mathrm{M} \mathrm{HCl}$ and $0.05 \mathrm{M}$ EDTA and implications for sediment-quality guidelines. Aust J Earth Sci 50:249-256

McLaughlin MJ, Zarcinas BA, Stevens DP, Cook N (2000) Soil testing for heavy metals. Commun. Soil Sci Plant Anal 31:1661-1700

Meers E, Du Laing G, Unamuno V, Ruttens A, Vangronsveld J, Tack FMG, Verloo GM (2007a) Comparison of cadmium extractability from soils by commonly used single extraction protocols. Geoderma 14:247-259

Meers E, Lamsal S, Vervaeke O, Hopgood M, Lust N, Tack FMG, Verloo MG (2005) Assessment of heavy metals bioavailability in a moderately contaminated dredged sediment disposal site and its potential for phytoextraction by Salix viminalis. Environ Pollut 137:354-364 
Meers E, Samsonb R, Tack FMG, Ruttens A, Vandegehuchte M, Vangronsveld J, Verloo MG (2007b) Phytoavailability assessment of heavy metals in soils by single extractions and accumulation by Phaseolus vulgaris. Environmental and Experimental Botany 60:385396

Menzies NW, Donn MJ, Kopittke PM (2007) Evaluation of extractants for estimation of the phytoavailable traces metals in soils. Environ Pollut 145:121-130

Navarro MC, Pe'rez-Sirvent C, Martı'nez-Sa'nchez MJ,Vidal J, Tovar PJ, Bech J (2008) Abandoned mine sites as a source of contamination by heavy metals: a casestudyinasemi-aridzone.J.Geochem.Explor.96:183-193

Menzies NW, Donn JM, Kopittke PM, 2007. Evaluation of extractants for estimation of the phytoavailable trace metals in soils. Environmental Pollution 145:121-130.

Negrel P, Grosbois C, Kloppmann W (2000) The labile fraction of suspended matter in the Loire River (France): multi-element chemistry and isotopic ( $\mathrm{Rb}-\mathrm{Sr}$ and $\mathrm{C}-\mathrm{O}$ ) systematics. Chem Geol 166:271-285

Norvell WA (1984) Comparison of Chelating Agents and Soil Materials. Soil Sci Soc Am J 48:1285-1292

Novozamsky I, Lexmond ThM, Houba VJG (1993) A single extraction procedure of soil for evaluation of uptake of some heavy metals by plants. Int J Environ Anal Chem 51:47-58

Nyamangara J (1998) Use of sequential extraction to evaluate zinc and copper in a soil amended with sewage sludge and inorganic metal salts. Agri Ecosyst Environ 69:135141

Pascual I, Antolin MC, Garcia C, Polo A, Sanchez-Diaz M (2004) Plant availability of heavy metals in a soil amended with a high dose of sewage sludge under drought conditions. Biol Fert Soils 40:291-299

Plaza GA, Nalecz-Jawecki G, Pinyakong O, Illmer P, Margesin R (2010) Ecotoxicological and microbiological characterization of soils from heavy-metal and hydrocarboncontaminated sites. Environ Monit Assess 163:477-488

Pueyo M, López-Sánchez JF, Rauret G (2004) Assessment of $\mathrm{CaCl}_{2}, \mathrm{NaNO}_{3}$ and $\mathrm{NH}_{4} \mathrm{NO}_{3}$ extraction procedures for the study of $\mathrm{Cd}, \mathrm{Cu}, \mathrm{Pb}$ and $\mathrm{Zn}$ extractability in contaminated soils. Analytica Chimica Acta 504:217-226

Qasim B, Motelica-Heino M (2014) Potentially toxic element fractionation in technosoils using two sequential extraction schemes. Environmental Science and Pollution Research 21:5054 - 5065

Quevauviller P, Rauret R, Rubio G, Lopezsanchez JF, Ure AM, Bacon JR, Muntau H (1997) Certified reference materials for the quality control of EDTA- and acetic acidextractable contents of trace elements in sewage sludge amended soils (CRMs 483 and 484). Fresenius J Anal Chem 357:611-618

Razo I, Carrizales L, Castro J, Di'az-Barriga F, Montoroy M (2004) Arsenic and heavy metal pollution of soil, water and sediments in a semi-aridclimate mining areain Mexico. Water Air Soil Pollut 152:129-152 
Rodriguez L, Ruiz E, Alonso-Azcarate J, Rincon J (2009) Heavy metal distribution and chemical speciation in tailings and soils around a $\mathrm{Pb}-\mathrm{Zn}$ mine in Spain. $\mathrm{J}$ Environnemental Management 90:1106-1116

Sahuquillo A, Rigol A, Rauret G (2003) Overview of the use of leaching/extraction test for risk assessment of the metals in contaminated soils and sediments. Trends in Analytical Chemistry 3:151-159

Sauerbeck DR (1991) Plant element and soil properties governing uptake and availability of heavy metals derived from sewage sludge. Water Air Soil Pollut 58:227-237

Serafimoviska JM, Arpadjan S, Stavilov T, Teskova K (2013) Study of the antimony species distribution in industrially contaminated soils. J Soils Sediments 13:294 - 303

Singh BW (2007) In Natural Attenuation of Trace Element Availability in Soils, Hamon R, Mclaughlin M, Lombi E (Eds.) Soc Environ Toxicol Chem Pensacola FL 1-18

Sloot HA van der, Comans RNJ, Hjelmar O (1996) Similarities in the leaching behavior of trace contaminants from waste, stabilized waste, construction materials and soil. Sci Total Environ 178:111-126

Smilde KW, Luit BV, Driel WV (1992) The extraction from soil and absorption by plants of applied Zn and Cd. Plant Soil 143:215-221

Spiter E, Rozsa E, Gruiz K, Tatrai E, Morvai V (2008) Site specific risk assessment in contaminated vegetable gardens. Chemosphere 71:1301-1307

Sutherland RA (2002) Comparison between non-residual Al, Co, Cu, Fe, $\mathrm{Mn} \mathrm{Ni}, \mathrm{Pb}$ and $\mathrm{Zn}$ released by a three-step sequential extraction procedure and a dilute hydrochloric acid leach for soil and road deposited sediment. Appl Geo chem 17:353-365

Száková J, Tlustoš P, Balík J, Pavlíková D, Balíková M (2001) A comparison of suitability of mild extraction procedures for determination of available portion of $\mathrm{As}, \mathrm{Cd}$, and $\mathrm{Zn}$ in soil. Chem Listy 95:179 - 183

Theodoratos P, Papassiopi N, Xenidis A (2002) Evaluation of monobasic calcium phosphate immobilization of heavy metals in contaminated soils from Lavrion. J Hazard Mater 94:135-146

Ure AM, Quevauviller Ph, Muntau H, Griepink B (1993) Speciation of heavy metal in soils and sediments. An account of the improvement and harmonisation of extraction techniques undertaken under the auspices of the BCR of the Commission of the European Communities. Int J Environ Anal Chem 51:135-151

Uzu G, Sobanska S, Pradere P, Dumat C (2009) Study of lead phytoavailability for atmospheric industrial micronic and sub-micronic particles in relation with lead speciation. Environ Pollut 157:1178-1185

Wanat N, Austruy A, Joussein E, Soubrand M, Hitmi A, Gauthier-Moussard C, Lenain JF, Vernay P, Munch JC, Pichon M (2013) Potentials of Miscanthus $\times$ giganteus grown on highly contaminated Technosols. J Geochem Explor 126-127: 78-84 
Wanat N, Joussein E, Soubrand M, Lenain JF (2014) Arsenic (As), antimony (Sb), and lead $(\mathrm{Pb})$ availability from Au-mine Technosols: a case study of transfer to natural vegetation cover in temperate climates. Environ Geochem Hlth. DOI 10.1007/s10653014-9596-5

Wang J, Zhang CB, Jin ZX (2009) The distribution and phytoavailability of heavy metal fractions in rhizosphere soils of Paulowniufortunei (seem) Hems near a $\mathrm{Pb} / \mathrm{Zn}$ smelter in Guangdong PR China. Geoderma 148:299-306

Whitten MG, Ritchie GSP (1991) Calcium chloride extractable cadmium as an estimate of cadmium uptake by subterranean clover. Aust J Soil Res 29:215-221

Xu D, Zhou P, Zhan J, Gao Y, Dou C, Sun Q (2013) Assessment of trace metal bioavailability in garden soils and health risks via consumption of vegetables in the vicinity of Tongling mining area, China. Ecotoxicology and Environmental Safety 90:103-111

Zhang J, Liu J, Li C, Nie Y, Jin Y (2008) Comparison of the fixation of heavy metals in raw material, clinker and mortar using a BCR sequential extraction procedure and NEN7341 test. Cement and Concrete Research 38:675-680 

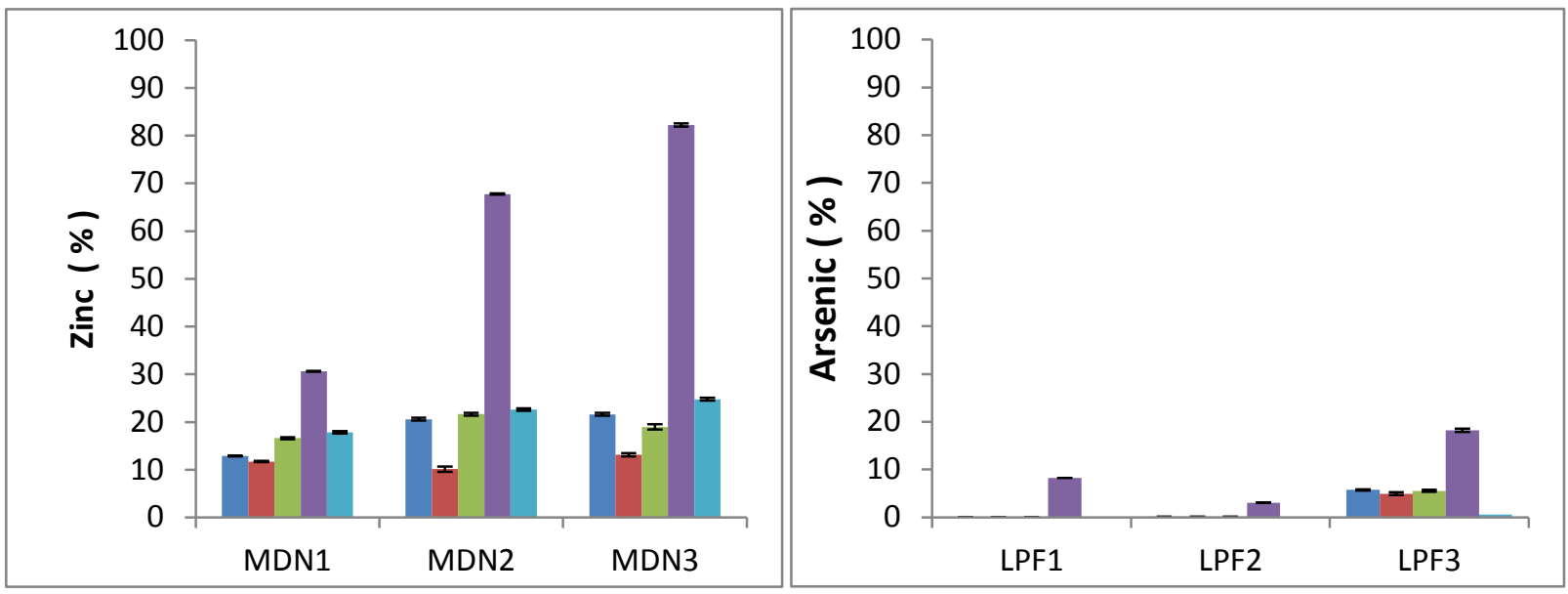

b

e
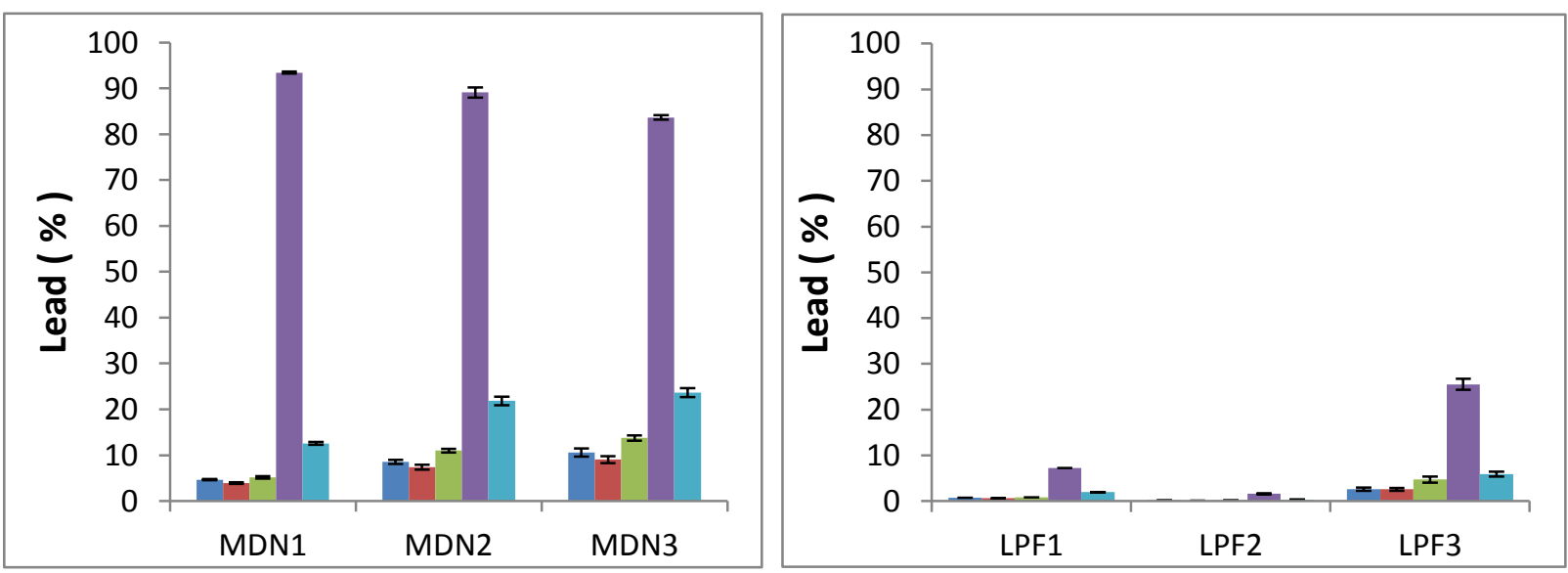

c
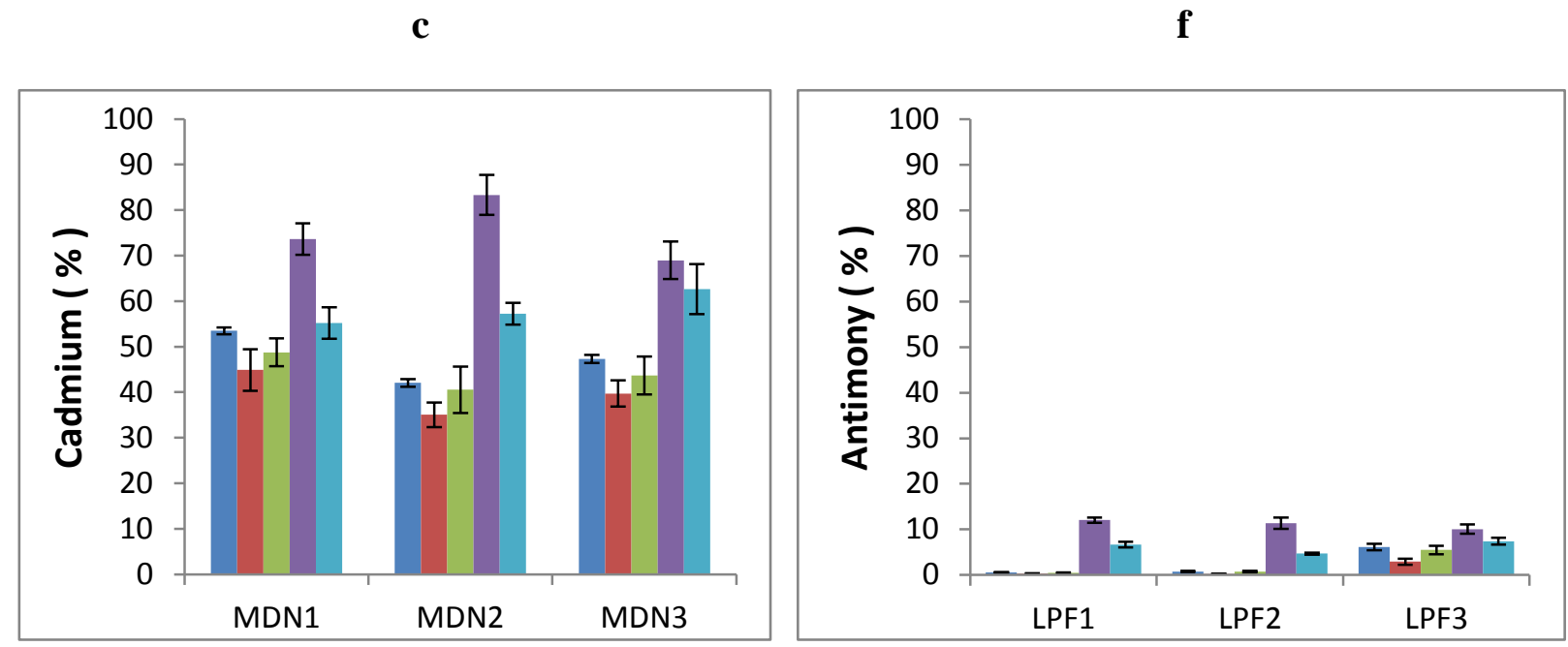

$\mathrm{CaCl} 2$

Fig. 1 Extractable potentially toxic elements ( $\mathrm{Zn}, \mathrm{Cd}, \mathrm{Pb}, \mathrm{As}$ and $\mathrm{Sb})(\%)$ by various single extractants $\left(\mathrm{CaCl}_{2}, \mathrm{NaNO}_{3}, \mathrm{NH}_{4} \mathrm{NO}_{3}\right.$, EDTA and DTPA) for MDN site (a, b and c) and LPF site (d, e and f). 
$\mathbf{a}$

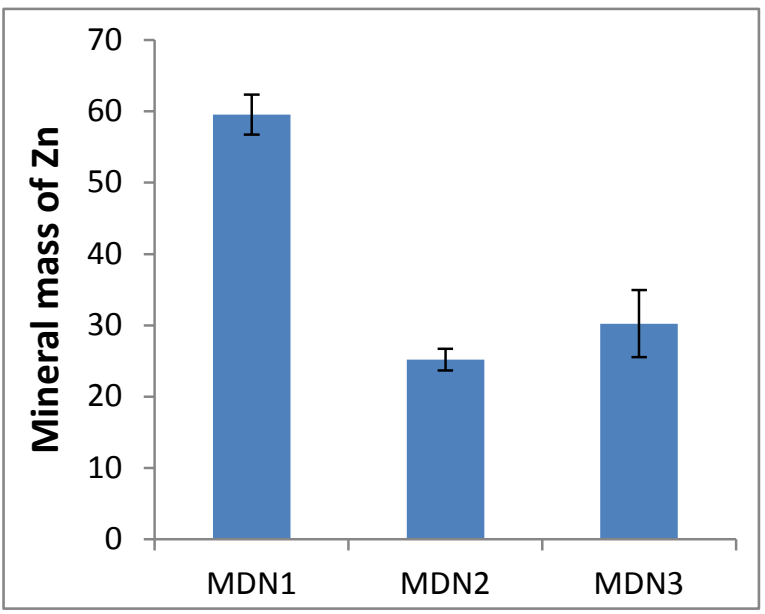

b

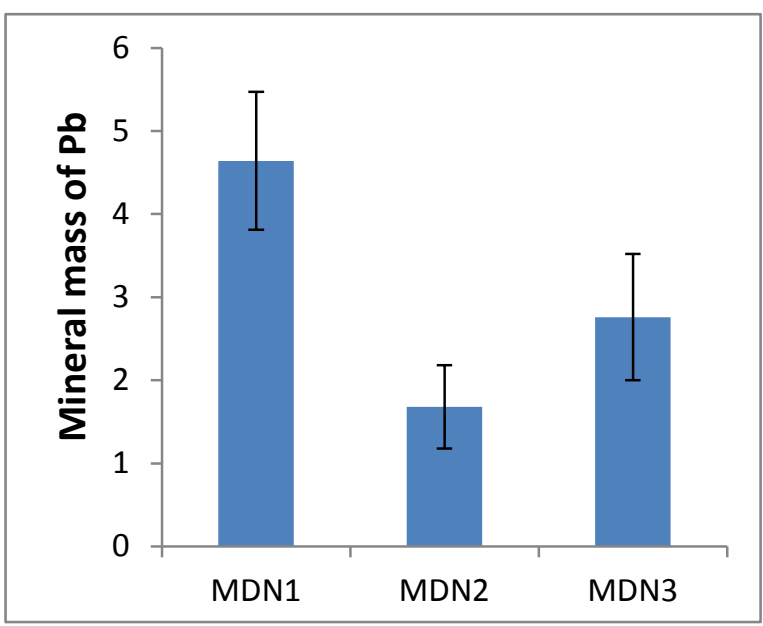

c

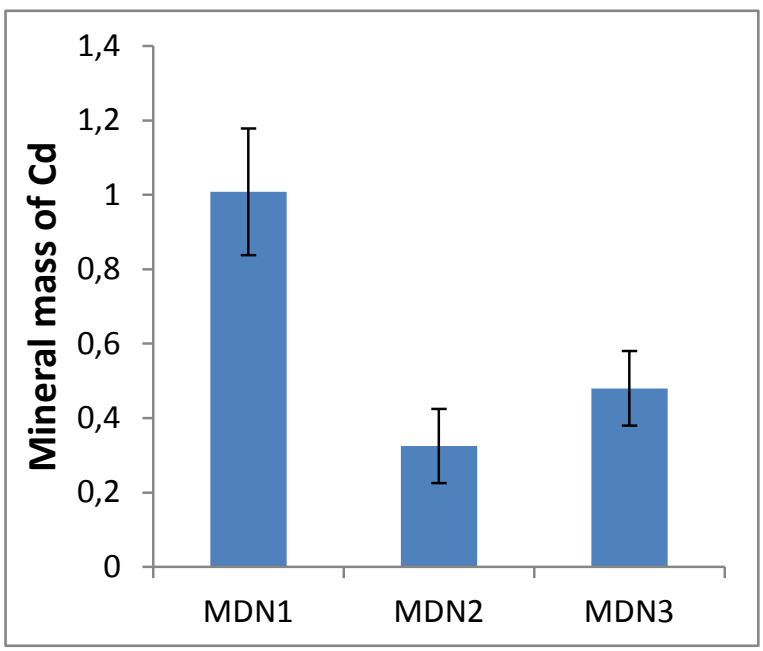

d

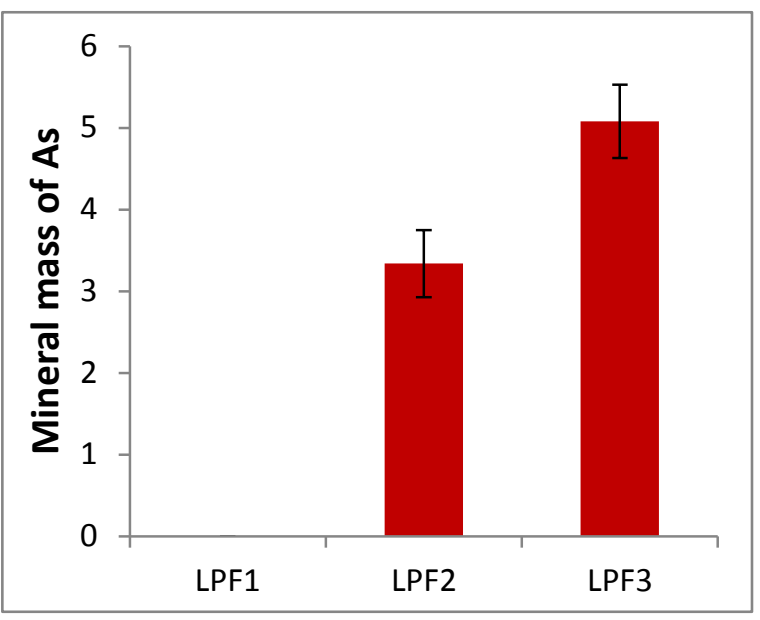

e
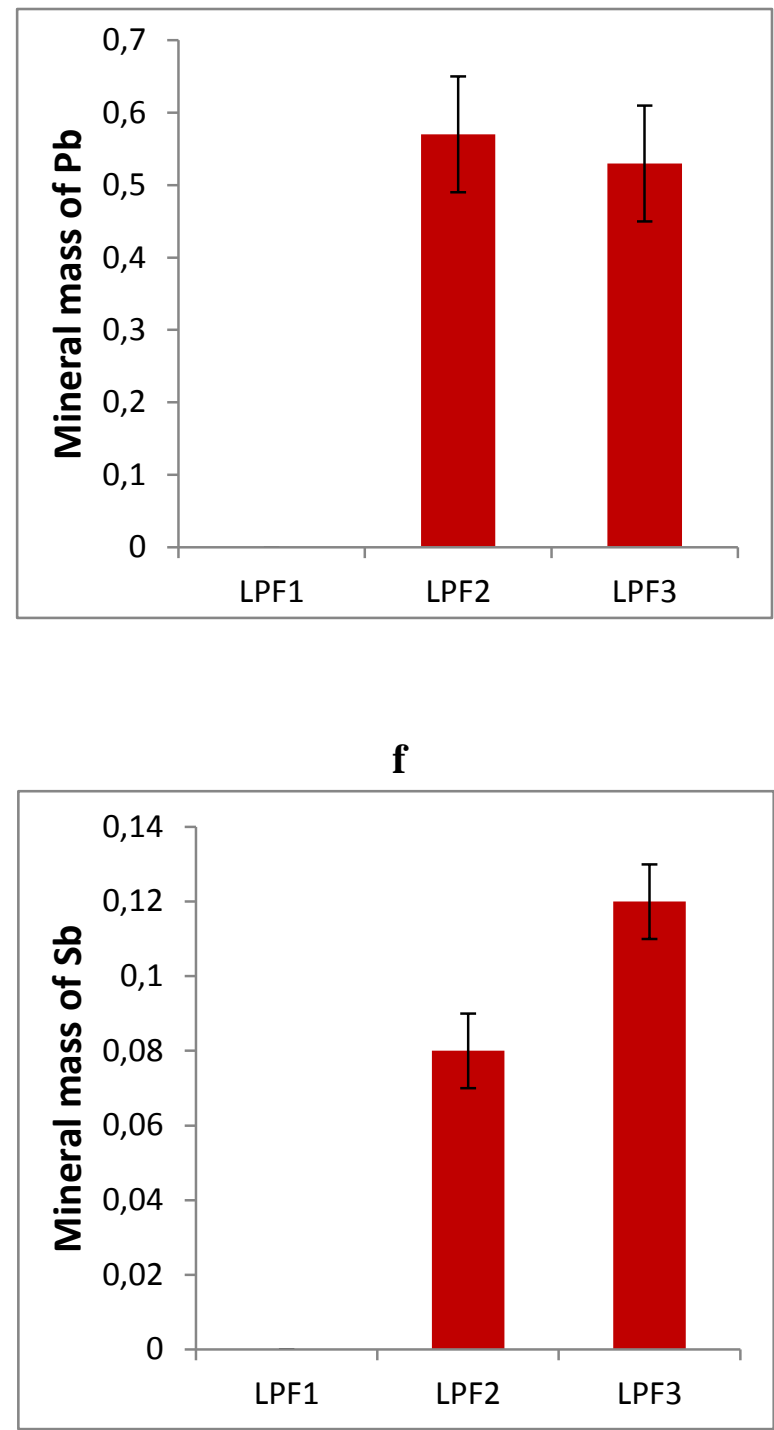

Figure 2 Mineral masses of $\mathrm{Zn}, \mathrm{Pb}, \mathrm{Cd}$, $\mathrm{As}$ and $\mathrm{Sb}$ (mg/plant) in the dwarf bean primary leaves for MDN site ( $a, b$ and $c$ ) and LPF* site (d, e and f).

* The plants in LPF1 were not growth. 
Table 1: Physico-chemical characteristics of the selected samples from Mortagne-du-Nord (MDN) and La Petite Faye (LPF) ( $\mathrm{n}=3 ; \pm$ standard deviation)

\begin{tabular}{|c|c|c|c|c|c|c|}
\hline \multirow[b]{2}{*}{ Parameters } & \multicolumn{3}{|c|}{ MDN samples } & \multicolumn{3}{|c|}{ LPF samples } \\
\hline & MDN1 & MDN2 & MDN3 & LPF1 & LPF2 & LPF3 \\
\hline $\mathrm{pH}-\mathrm{H}_{2} \mathrm{O}$ & $6.92 \pm 0.12$ & $6.35 \pm 0.34$ & $6.14 \pm 0.17$ & $3.65 \pm 0.05$ & $4.93 \pm 0.4$ & $5.75 \pm 0.1$ \\
\hline $\mathrm{pH}-\mathrm{KCl}$ & $6.58 \pm 0.2$ & $6.02 \pm 0.2$ & $5.89 \pm 0.7$ & $3.42 \pm 0.1$ & $4.57 \pm 0.3$ & $5.61 \pm 0.1$ \\
\hline $\mathrm{EC}$ & $112 \pm 3$ & $112 \pm 7$ & $113 \pm 1$ & $258 \pm 4$ & $200 \pm 3$ & $150 \pm 3$ \\
\hline OM \% & $8.26 \pm 2.3$ & $10.28 \pm 1.4$ & $13.84 \pm 0.7$ & $6.46 \pm 3.4$ & $5.27 \pm 1.1$ & $6.83 \pm 0.9$ \\
\hline CEC & $7.2 \pm 0.7$ & $8.5 \pm 0.2$ & $6.7 \pm 1.2$ & $18.3 \pm 0.7$ & $29.1 \pm 0.2$ & $39.7 \pm 0.3$ \\
\hline TOC \% & $3.35 \pm 0.9$ & $4.39 \pm 0.1$ & $6.45 \pm 0.1$ & $0.3 \pm 0.8$ & $0.47 \pm 0.4$ & $1.67 \pm 0.8$ \\
\hline Clay \% & $0.95 \pm 0.24$ & $0.86 \pm 0.01$ & $0.9 \pm 0.24$ & $3.79 \pm 0.34$ & $1.07 \pm 1.03$ & $2.02 \pm 0.41$ \\
\hline Silt \% & $22.3 \pm 0.35$ & $22.16 \pm 0.41$ & $22.13 \pm 0.34$ & $48.09 \pm 0.54$ & $19.81 \pm 0.24$ & $39.14 \pm 0.23$ \\
\hline Sand \% & $75.45 \pm 0.12$ & $76.84 \pm 1.03$ & $76.66 \pm 0.28$ & $48.12 \pm 0.1$ & $78.6 \pm 0.64$ & $58.8 \pm 0.03$ \\
\hline
\end{tabular}

Table 2: Pseudo total potentially toxic element content $\left(\mathrm{mg}^{\mathrm{kg}} \mathrm{kg}^{-1}\right)$ for the selected samples from Mortagne-du-Nord (MDN) and La Petite Faye (LPF) ( $\mathrm{n}=3 ; \pm$ standard deviation)

Sample

\begin{tabular}{cllc}
\hline & & & \\
& Zn & \multicolumn{1}{c}{ Pb } & Cd \\
MDN 1 & $7726 \pm 12$ & $3551 \pm 10$ & $72 \pm 11$ \\
MDN 2 & $3114 \pm 11$ & $881 \pm 8$ & $64 \pm 5$ \\
MDN 3 & $3127 \pm 9$ & $874 \pm 5$ & $51 \pm 6$ \\
& & & \\
& As & Pb & Sb \\
LPF 1 & $83941 \pm 11$ & $16109 \pm 13$ & $863 \pm 8$ \\
LPF 2 & $37462 \pm 8$ & $8541 \pm 7$ & $493 \pm 7$ \\
LPF 3 & $2672 \pm 4$ & $367 \pm 4$ & $107 \pm 9$
\end{tabular}


Table 3: Extractable potentially toxic element content in the selected (MDN) samples (mg.kg$\left.{ }^{1}\right)(\mathrm{n}=3 ; \pm$ standard deviation $)$

$\begin{array}{llll}\text { Element } & \text { MDN 1 } & \text { MDN 2 } & \text { MDN 3 }\end{array}$

\section{Zn}

$\mathrm{CaCl}_{2}$

$993.4 \pm 7$

$\mathrm{NaNO}_{3}$

$906.6 \pm 2$

$642.8 \pm 9$

$674.5 \pm 3$

$\mathrm{NH}_{4} \mathrm{NO}_{3}$

$1082.4 \pm 4$

$315.6 \pm 4$

$409.2 \pm 1$

EDTA

$2366 \pm 3$

$674.6 \pm 0.3$

$591.6 \pm 1$

DTPA

$1375.3 \pm 1$

$2113.2 \pm 7$

$2564 \pm 0.9$

$611.6 \pm 2$

$772 \pm 0.2$

Pb

$\mathrm{CaCl}_{2}$

$166.1 \pm 4$

$74.78 \pm 3$

$93.2 \pm 1$

$\mathrm{NaNO}_{3}$

$137.5 \pm 1$

$64.14 \pm 0.4$

$80.64 \pm 4$

$\mathrm{NH}_{4} \mathrm{NO}_{3}$

$182.5 \pm 0.6$

$96.28 \pm 4$

$120.6 \pm 0.1$

EDTA

$3318 \pm 2$

$780 \pm 1$

$731 \pm 7$

DTPA

$446.2 \pm 7$

$191.2 \pm 3$

$206.3 \pm 5$

\section{Cd}

$\mathrm{CaCl}_{2}$

$35.8 \pm 0.9$

$25.24 \pm 1$

$27.4 \pm 1.6$

$\mathrm{NaNO}_{3}$

$30.08 \pm 2.3$

$21.22 \pm 0.6$

$23.2 \pm 2.5$

$\mathrm{NH}_{4} \mathrm{NO}_{3}$

$32.8 \pm 1.7$

$24.2 \pm 1$

$25.4 \pm 2$

EDTA

$49.2 \pm 2$

$50 \pm 3$

$40 \pm 0.8$

DTPA

$37 \pm 2.4$

$34.6 \pm 0.3$

$36.2 \pm 2$ 
Table 4: Extractable potentially toxic element content in the selected (LPF) samples (mg. $\mathrm{kg}^{-}$ 1) $(\mathrm{n}=3 ; \pm$ standard deviation $)$

$\begin{array}{llll}\text { Element } & \text { LPF1 LPF2 }\end{array}$

As

$\begin{array}{llll}\mathrm{CaCl}_{2} & 43.07 \pm 4 & 62.62 \pm 0.9 & 153.22 \pm 1 \\ \mathrm{NaNO}_{3} & 20.59 \pm 1 & 43.04 \pm 1.1 & 132.52 \pm 0.6 \\ \mathrm{NH}_{4} \mathrm{NO}_{3} & 36.72 \pm 0.6 & 51.48 \pm 0.2 & 148.02 \pm 1.3 \\ \text { EDTA } & 6931.2 \pm 2 & 1151 \pm 1 & 486.8 \pm 2.1 \\ \text { DTPA } & 5.17 \pm 0.7 & 14.1 \pm 0.8 & 15.3 \pm 3.3\end{array}$

Pb

$\mathrm{CaCl}_{2}$

$117.8 \pm 2$

$17.48 \pm 2.4$

$9.52 \pm 1.7$

$\mathrm{NaNO}_{3}$

$101.34 \pm 0.8$

$11.3 \pm 1$

$9.4 \pm 2.1$

$\mathrm{NH}_{4} \mathrm{NO}_{3}$

$137.32 \pm 4$

$19.7 \pm 0.01$

$17.3 \pm 0.4$

EDTA

$1167 \pm 0.2$

$137.2 \pm 3$

$93.4 \pm 0.03$

DTPA

$314.5 \pm 5$

$25.42 \pm 6$

$21.5 \pm 1.4$

Sb

$\mathrm{CaCl}_{2}$

$4.6 \pm 2.7$

$3.7 \pm 1.3$

$6.96 \pm 0.4$

$\mathrm{NaNO}_{3}$

$2.5 \pm 0.6$

$1.04 \pm 2.9$

$3.3 \pm 0.7$

$\mathrm{NH}_{4} \mathrm{NO}_{3}$

$3.8 \pm 2.4$

$3.4 \pm 4$

$6.24 \pm 2$

EDTA

$103.6 \pm 4$

$55.2 \pm 3$

$11.4 \pm 1$

DTPA

$57 \pm 1.1$

$22.7 \pm 2.7$

$8.4 \pm 0.6$ 
Table 5: Total potentially toxic element content in primary bean leaves (DW) after 21 days in the selected (MDN) and (LPF) samples (mg.kg-1 DW) (n=3; \pm standard deviation)

Sample

\begin{tabular}{llll} 
& \multicolumn{1}{c}{ Zn } & \multicolumn{1}{c}{ Pb } & \multicolumn{1}{c}{ Cd } \\
MDN1 & $372.5 \pm 2.8$ & $29.24 \pm 2$ & $6.30 \pm 0.4$ \\
MDN2 & $240 \pm 1.5$ & $16 \pm 1$ & $3.12 \pm 0.1$ \\
MDN3 & $252.7 \pm 4.7$ & $23.3 \pm 0.5$ & $4.02 \pm 1$
\end{tabular}

As

LPF1

LPF2

LPF3
$\mathrm{Ng}$

$55.70 \pm 4$

$72.76 \pm 2.8$
Element

$\mathrm{Ng}$, no growth

Table 6: Pearson's correlation coefficients between potentially toxic element concentrations in primary bean leaves and their extractable concentrations by different single extraction procedures for MDN and LPF samples.

Primary bean leaves after 21days (DW)

\begin{tabular}{|c|c|c|c|c|c|c|}
\hline \multirow[b]{2}{*}{ Extraction } & \multicolumn{3}{|c|}{ MDN samples } & \multicolumn{3}{|c|}{ LPF samples } \\
\hline & $\mathrm{Zn}$ & $\mathrm{Pb}$ & $\mathrm{Cd}$ & As & $\mathrm{Sb}$ & $\mathrm{Pb}$ \\
\hline $\mathrm{CaCl}_{2}$ & $0.99 * *$ & $0.90 * *$ & $0.94 * *$ & $0.86^{*}$ & $0.88^{*}$ & $0.91 *$ \\
\hline $\mathrm{NaNO}_{3}$ & $0.99 * *$ & $0.89 * *$ & $0.80 * *$ & $0.92 * *$ & $0.64^{\mathrm{NS}}$ & $0.69^{\mathrm{NS}}$ \\
\hline $\mathrm{NH}_{4} \mathrm{NO}_{3}$ & $0.97 * *$ & $0.93 * *$ & $0.84^{*}$ & $0.87 *$ & $0.78 *$ & $0.88 *$ \\
\hline EDTA & $0.14^{\mathrm{NS}}$ & $0.81 *$ & $0.01^{\mathrm{NS}}$ & $0.28^{\mathrm{NS}}$ & $0.44^{\mathrm{NS}}$ & $0.89 *$ \\
\hline DTPA & $0.67^{\mathrm{NS}}$ & $0.85^{* *}$ & $0.23^{\mathrm{NS}}$ & $0.42^{\mathrm{NS}}$ & $-0.78^{\mathrm{NS}}$ & $0.90 *$ \\
\hline
\end{tabular}

** Correlation is significant at the 0.01 level; * correlation is significant at the 0.05 level; NS, no significant correlation. 
Table 7: Pearson's correlation coefficients between foliar potentially toxic element mineral mass and their extractable concentrations by different single extraction procedures for MDN and LPF samples.

\begin{tabular}{|c|c|c|c|c|c|c|}
\hline \multirow[b]{3}{*}{ Extraction } & \multicolumn{6}{|c|}{ Primary bean leaves after 21days (DW) } \\
\hline & \multicolumn{3}{|c|}{ MDN samples } & \multicolumn{3}{|c|}{ LPF samples } \\
\hline & $\mathrm{Zn}$ & $\mathrm{Pb}$ & $\mathrm{Cd}$ & As & $\mathrm{Sb}$ & $\mathrm{Pb}$ \\
\hline $\mathrm{CaCl}_{2}$ & $0.99 * *$ & $0.87 *$ & $0.95^{* *}$ & $0.80^{*}$ & $0.6^{\mathrm{NS}}$ & $0.28^{\mathrm{NS}}$ \\
\hline $\mathrm{NaNO}_{3}$ & $0.99 * *$ & $0.86^{*}$ & $0.93 * *$ & $0.83^{*}$ & 0.21 & $0.67^{\mathrm{NS}}$ \\
\hline $\mathrm{NH}_{4} \mathrm{NO}_{3}$ & $0.96^{* *}$ & $0.91^{* *}$ & $0.81^{* *}$ & $0.81^{* *}$ & $0.65^{*}$ & $0.03^{\mathrm{NS}}$ \\
\hline EDTA & $0.2^{\mathrm{NS}}$ & $0.83 * *$ & $0.2^{\mathrm{NS}}$ & $-0.76^{\mathrm{NS}}$ & $-0.48^{\mathrm{NS}}$ & $-0.15^{\mathrm{NS}}$ \\
\hline DTPA & $0.49^{\mathrm{NS}}$ & $0.86 * *$ & $0.04^{\mathrm{NS}}$ & $0.51^{\mathrm{NS}}$ & $-0.58^{\mathrm{NS}}$ & $-0.24^{\mathrm{NS}}$ \\
\hline
\end{tabular}

** Correlation is significant at the 0.01 level; * correlation is significant at the 0.05 level; NS, no significant correlation. 